\title{
A PRELIMINARY SURVEY OF THE METEOROLOGY OF KIMBERLEY.
}

\author{
By J. R. Sutton, Sc.D., F.R.S.S.Af.
}

(Received October 9, 1912.)

(Read October 16, 1912.)

The present paper is intended as a further contribution to the meteorology of the Table-land of South Africa, arranged in a form suitable to the requirements of the physicist. Earlier instalments of the same series appeared from time to time in the Transactions of the South African Philosophical Society. The results given are deduced from observations made at Kenilworth (Kimberley) during the fifteen years 1897-1911. They show, in addition to yearly means and totals, deviations from the monthly mean values of all the more important recognised meteorological elements referred to the deviations from the monthly mean wind-direction resultant as argument. They are almost entirely statistical and tabular, and require very little in the way of explanatory setting at this time. Such results as these made at various places throughout the world have a certain amount of importance in view of the researches of Hildebrandsson and others on the centres of action of the atmosphere, and for other reasons.

Table 1 gives the mean monthly direction of the wind deduced from the continuous records of an Osler anemometer. The Table shows the north and east components in hours; the azimuth measured from the east point round by north; and the magnitude of the resultant. The north component is at its maximum in February and July, and at its minimum in May and October; while the east component has one maximum in June and one minimum in December. Thus there is a double oscillation in the year, the resultant direction starting from about north in January, tending gradually to about east in May, turning slightly towards the north in June and July, after which it travels forward from east round by south and west for the rest of the year. The mean direction is about east by north and the magnitude of the resultant 1,083 hours. Table 2 shows that the resultant in any one year will probably not differ greatly from this mean value either in direction or magnitude-1897 and 1911 being exceptional years.

Table 3 gives the monthly deviations from the monthly means of 
Table 1. The azimuths are counted plus when the deviation is counterclockwise up to $180^{\circ}$, and minus when it is clockwise up to the same angular distance. Thus the mean azimuth in January, 1897 , was $122^{\circ}$, and because the normal mean azimuth for January is $85^{\circ}$ the deviation appears as $+37^{\circ}$. The individual monthly azimuths vary much more widely from the normal means than the annual ones do, the range of deviation being the best part of two right angles on one side or the other of the normal. So also the monthly deviations of the magnitude of the resultants given in Table 4 are considerable.

\begin{tabular}{|c|c|c|c|}
\hline & Kenilworth. & Kimberley. & Difference. \\
\hline 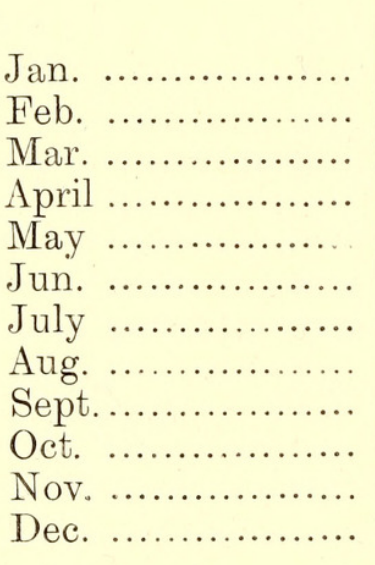 & $\begin{array}{r}\text { Inches. } \\
26 \cdot 047 \\
\cdot 080 \\
\cdot 063 \\
.202 \\
\cdot 190 \\
.319 \\
\cdot 214 \\
.234 \\
\cdot 165 \\
\cdot 070 \\
\cdot 041 \\
\cdot 023\end{array}$ & $\begin{array}{r}\text { Inches. } \\
25 \cdot 970 \\
26 \cdot 013 \\
25 \cdot 993 \\
26 \cdot 131 \\
\cdot 117 \\
.242 \\
\cdot 140 \\
\cdot 161 \\
.096 \\
.000 \\
25 \cdot 967 \\
.951\end{array}$ & $\begin{array}{l}\text { Inch. } \\
\cdot 077 \\
\cdot 067 \\
\cdot 070 \\
\cdot 071 \\
\cdot 073 \\
\cdot 077 \\
\cdot 074 \\
\cdot 073 \\
\cdot 069 \\
\cdot 070 \\
\cdot 074 \\
\cdot 072\end{array}$ \\
\hline Year ................. & $26 \cdot 137$ & $26 \cdot 065$ & .072 \\
\hline
\end{tabular}

Table 5 gives the deviations of each month's mean wind velocity from the normal means. The normal means are shown at the foot of the Table. If this Table could be entirely trusted, the last column (showing the annual deviations) would indicate a more or less gradual falling off in the velocity of the wind year by year. It is probable, however, that this result is partly real and partly due-

(1) To some wearing of the bearings of the Robinson anemometer, and (2) to some gradually increasing obstruction to the exposure of the instrument by growing trees. From a meteorological point of view these trees are a great nuisance. They seriously handicap not a few of the observations made at Kenilworth, and cannot, besides, by any stretch of the imagination, be called beautiful. As to the wearing of the bearings, this, such as it is, is caused by the grit which is blown about in every dust-storm, and which penetrates everywhere.

Table 6 gives the plus and minus values of barometric pressure for 
Kenilworth derived from readings of a large observatory standard barometer-the readings being made three times a day, at VIII., XIV., and XX., civil time. The mean of the pressures at these hours is practically the same as the mean of the hourly readings.

The late Mr. G. J. Lee took a series of meteorological observations from $1890-7$ at his own second-order station in Jones Street, Kimberley. His observations of pressure were made at VIII. and XX. with a small Fortin barometer, and considering the difference of altitude between Kimberley and Kenilworth, they compare very well with those of Kenilworth. The Jones Street results have been computed and shown in Table 7 . The table on the opposite page gives the respective monthly means for 1897 .

After reducing the Kimberley annual means to the Kenilworth level, and smoothing the values in threes by Bloxam's method, we have the following series, some corresponding values for Durban and Mauritius being added for purposes of comparison :-

\begin{tabular}{|c|c|c|c|}
\hline & Kenilworth. & Durban. & Mauritius. \\
\hline 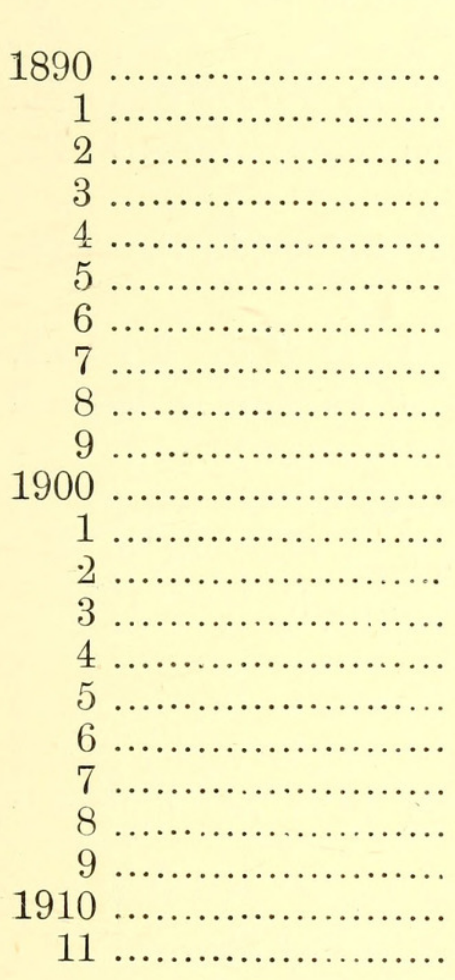 & $\begin{array}{c}\text { Inch. } \\
(-\cdot 007) \\
-\cdot 010 \\
-\cdot 012 \\
-\cdot 012 \\
-\cdot 005 \\
+\cdot 003 \\
+\cdot 004 \\
+\cdot 009 \\
+\cdot 010 \\
+\cdot 008 \\
+\cdot 007 \\
\cdot 000 \\
-\cdot 004 \\
--.005 \\
-\cdot 003 \\
+\cdot 003 \\
+\cdot 001 \\
-\cdot 001 \\
-\cdot 002 \\
-\cdot 006 \\
+\cdot 001 \\
(+\cdot 013)\end{array}$ & $\begin{array}{c}\text { Inch. } \\
+\cdot 011 \\
-\cdot 009 \\
-\cdot 011 \\
-\cdot 013 \\
-\cdot 002 \\
+\cdot 004 \\
\cdot 000 \\
+\cdot 001 \\
+\cdot 006 \\
+\cdot 006 \\
+\cdot 011 \\
-\cdot 003 \\
-\cdot 005 \\
-\cdot 011 \\
-\cdot 007 \\
-\cdot 003 \\
+\cdot 003 \\
+\cdot 005 \\
(\cdot 000)\end{array}$ & $\begin{array}{r}\text { Inch. } \\
+\cdot 014 \\
+.002 \\
+.005 \\
-.009 \\
-.004 \\
-.006 \\
.000 \\
-.003 \\
-.003 \\
+.006 \\
+.017\end{array}$ \\
\hline
\end{tabular}

Thus the irregular oscillations of pressure of long period, in the southern anticyclone belt, affect Kimberley and Durban similarly, but not Mauritius. 
Table 8 gives the monthly deviation of the duration of sunshine from the normal means-shown as in the other Tables at the foot; and Table 9 the cloudiness of the sky. The numbers in these two Tables are, as a rule, the inverse of each other, the cloudiness tending to a maximum when the sunshine is a minimum.

Table 10 gives the monthly durations of rainfall in hours. The yearly deviations are shown in the last column.

Tables 11 and 12 give the approximate duration of electrical phenomena from eye and ear observations. The numbers in these two Tables, especially the latter, must be regarded as lower limits, for some thunder must escape hearing, and some lightning must escape attention on account of the obstruction to the horizon by trees.

The five Tables 8-12 are in fair agreement with each other; but neither exhibits such concordance with Table 6 as might have been expected.

Table 13 gives the deviation values for what is called the "temperature in the sun" as registered by a maximum black bulb in vacuo. In this Table the year 1909 is remarkable, every month save February showing a temperature higher than the normal mean of the month. Of the year 1897 the same may be said, though to a less degree. The year 1909 was the most clouded year of the period, while, curiously enough, 1897 had the least cloud. The monthly maximum temperatures in the shade show no such agreement (Table 14).

Tables 15 and 16 give minimum temperature deviations, in the shade and over a grass lawn respectively.

Tables 17, 18, 19 give respectively the temperatures of the dry bulb, the temperatures of the dew-point, and the relative humidities deduced from hourly readings of the dry and wet bulb thermometers.

Table 20 is supplementary to the general purpose of this paper. It gives the rainfall of Kimberley from 1877 to 1896, as observed by the late Mr. F. W. Matthews, and the rainfall of Kenilworth from 1894 to 1911.

Comparing now the monthly plus and mimus values of the deviation from the normal wind direction with the plus and minus values of the other elements (leaving out zero deviations), we have the following results :-

\begin{tabular}{|c|c|c|}
\hline Magnitude of resultant & $\begin{array}{l}\text { Like Sign. } \\
\quad 93 \text { times }\end{array}$ & $\begin{array}{r}\text { Unlike Sign. } \\
82 \text { times }\end{array}$ \\
\hline Barometric pressure ........... & 104 & 68 \\
\hline Sunshine ....................... & 82 & 83 \\
\hline Cloud .................... & 88 & 74 \\
\hline Thunderstorms ........... & 82 & 81 \\
\hline
\end{tabular}




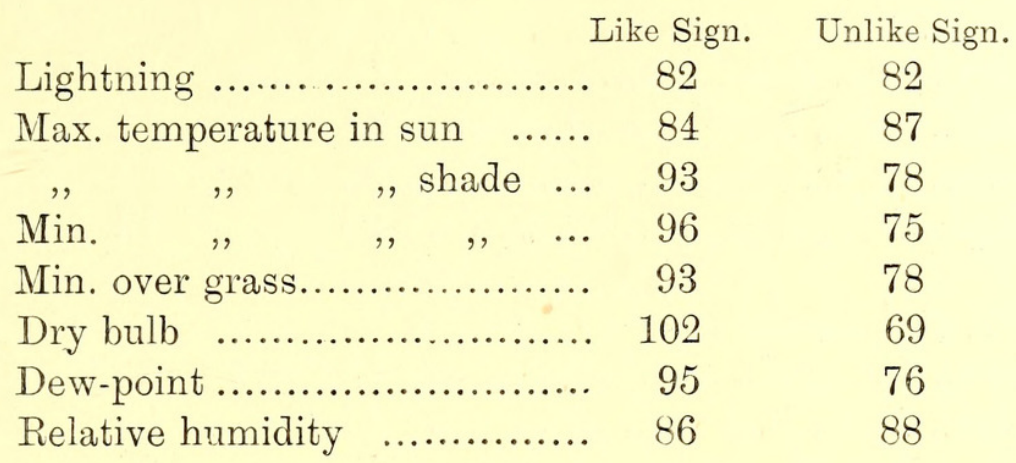

The meaning of this summary will be understood from a single example: In 172 months the barometric-pressure deviation and the wind-resultant deviation were both positive or both negative (i.e., they had the same sign) 104 times; while in the remaining 68 times the deviations of the two were in opposite directions (i.e., they had unlike signs).

But on the whole it may be said that the above summary shows no very strong dependence of the greater number of the elements upon the deviation of the wind-direction resultant from its normal mean direction. If, however, the comparison be made month by month, a much better case is made out. For example, if the sunshine deviations be taken in periods of three months each, we get the following numbers:-

\begin{tabular}{|c|c|c|}
\hline $\begin{array}{l}\text { I } \\
. .\end{array}$ & $\begin{array}{l}\text { Like Sign. } \\
\text {. } 27 \text { times }\end{array}$ & $\begin{array}{l}\text { Unlike Sign. } \\
14 \text { times }\end{array}$ \\
\hline Mar., April, May ................. & 20 & 23 \\
\hline June, July, Aug..................... & 24 & 18 \\
\hline Sept., Oct., Nov...................... & 11 & 28 \\
\hline
\end{tabular}

That is, in December-February and in June-August the sunshine deviations and the azimuth deviations agree in the majority of cases. Now in the period December-February the mean resultant direction of the wind is nearly north, and in the period June-August nearly east. Hence in the first period an excess of sunshine will accompany a deviation to the west in the direction of the wind; and in the second period there will be an excess of sunshine when the vane tends more to the north. Again, in the period September-November the mean resultant is southerly; and in this period we get less sunshine when the deviation is towards the east, and more sunshine when the deviation is towards the west. Of the cloudiness of the sky practically the opposite may be said. Thus on the whole a westerly tendency in the wind indicates clearer skies, and an easterly tendency more cloud, and also more thunderstorms and more sheet-lightning. The following are the numbers for these three elements :- 


\begin{tabular}{|c|c|c|}
\hline 1. Cloud. & Like Sign. & Unlike Sign. \\
\hline Dec., Jan., Feb. .................... & - 12 times & 28 times \\
\hline Mar., April, May ................. & 27 & 14 \\
\hline June, July, Aug.................... & 21 & 20 \\
\hline Sept., Oct., Nov..................... & 28 & 12 \\
\hline
\end{tabular}

2. Thunderstorms.

\begin{tabular}{|c|c|c|}
\hline Dec., Jan., Feb. ................... & 15 times & 26 times \\
\hline Mar., April, May ................ & 19 & 24 \\
\hline June, July, Aug ..................... & 22 & 18 \\
\hline Sept., Oct., Nov................... & 26 & 13 \\
\hline 3. Lightning. & & \\
\hline Dec., Jan., Feb. . & 14 times & 29 times \\
\hline Mar., April, May & 25 & 18 \\
\hline June, July, Aug. ...................... & 22 & 17 \\
\hline Sept., Oct., Nov...................... & 21 & 18 \\
\hline
\end{tabular}

In summer the maximum temperature in the shade rises or falls according as the deviation of the resultant wind direction is positive or negative, whereas in the spring the case is the other way about. Thus in both seasons a deviation to the west in the vane means an increase of temperature. The minimum temperatures, both in the shade and over the grass, on the other hand, are higher when the vane tends easterly.

Lastly, in the summer the temperature of the dew-point rises as the vane tends easterly; whereas for the rest of the year the rise corresponds with a positive deviation in the resultant direction of the wind. 
TABLE 1.

Mean Resultant Direction of the Wind, 1897-1911.

\begin{tabular}{|c|c|c|c|c|}
\hline & North. & East. & Azimuth. & Magnitude. \\
\hline 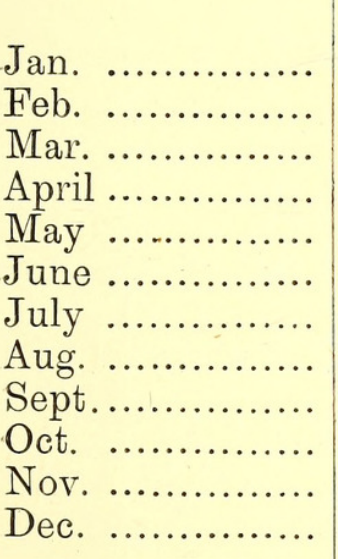 & $\begin{array}{l}\text { Hours. } \\
+104 \\
+114 \\
+\quad 65 \\
+\quad 46 \\
+\quad 5 \\
+\quad 25 \\
+73 \\
+\quad 3 \\
-\quad 6 \\
-100 \\
-72 \\
-\quad 11\end{array}$ & $\begin{array}{l}\text { Hours. } \\
+\quad 9 \\
+\quad 77 \\
+128 \\
+131 \\
+149 \\
+183 \\
+206 \\
+107 \\
+\quad 85 \\
+19 \\
-15 \\
-23\end{array}$ & $\begin{array}{r}\circ \\
85 \\
56 \\
27 \\
19 \\
2 \\
8 \\
19 \\
2 \\
356 \\
280 \\
258 \\
205\end{array}$ & $\begin{array}{l}\text { Hours. } \\
104 \\
137 \\
143 \\
139 \\
150 \\
184 \\
219 \\
107 \\
85 \\
102 \\
74 \\
26\end{array}$ \\
\hline Year .............. & +245 & +1055 & 13 & 1083 \\
\hline
\end{tabular}

TABLE 2.

Annual Resultant Direction of the Wind.

\begin{tabular}{|c|c|c|c|c|}
\hline ' & North. & East. & Azimuth. & Magnitude. \\
\hline 1897. & $\begin{array}{l}\text { Hours. } \\
-\quad 500\end{array}$ & $\begin{array}{l}\text { Hours. } \\
-\quad 245\end{array}$ & $24 \stackrel{\circ}{2}$ & $\begin{array}{l}\text { Hours. } \\
557\end{array}$ \\
\hline 1898 .............. & +296 & +1420 & 12 & 1451 \\
\hline $1899 \quad \ldots \ldots \ldots \ldots \ldots$ & +128 & +1542 & 5 & 1547 \\
\hline $1900 \quad \ldots \ldots \ldots \ldots \ldots$ & +167 & +887 & 11 & 903 \\
\hline 1901 ............. & +468 & +878 & 28 & 995 \\
\hline 1902 , ............. & +396 & +1168 & 19 & 1233 \\
\hline 1903 ............... & +199 & +568 & 19 & 602 \\
\hline 1904 ................ & $\begin{array}{r}+277 \\
+\quad 2\end{array}$ & +1205 & 13 & 1236 \\
\hline 1905 .............. & +844 & $\begin{array}{r}+931 \\
+\quad 2\end{array}$ & 42 & 1257 \\
\hline 1906 .............. & +592 & +817 & 36 & 1009 \\
\hline 1907 ............... & +453 & +1420 & 18 & 471 \\
\hline 1908 ........... & +135 & +599 & 13 & 614 \\
\hline 1909 ............ & +1114 & +1442 & 38 & 1822 \\
\hline 1910 ............. & $\begin{array}{r}+459 \\
\end{array}$ & +1431 & 18 & 1503 \\
\hline 1911 ............. & $-\quad 18$ & +1701 & 359 & 1701 \\
\hline
\end{tabular}




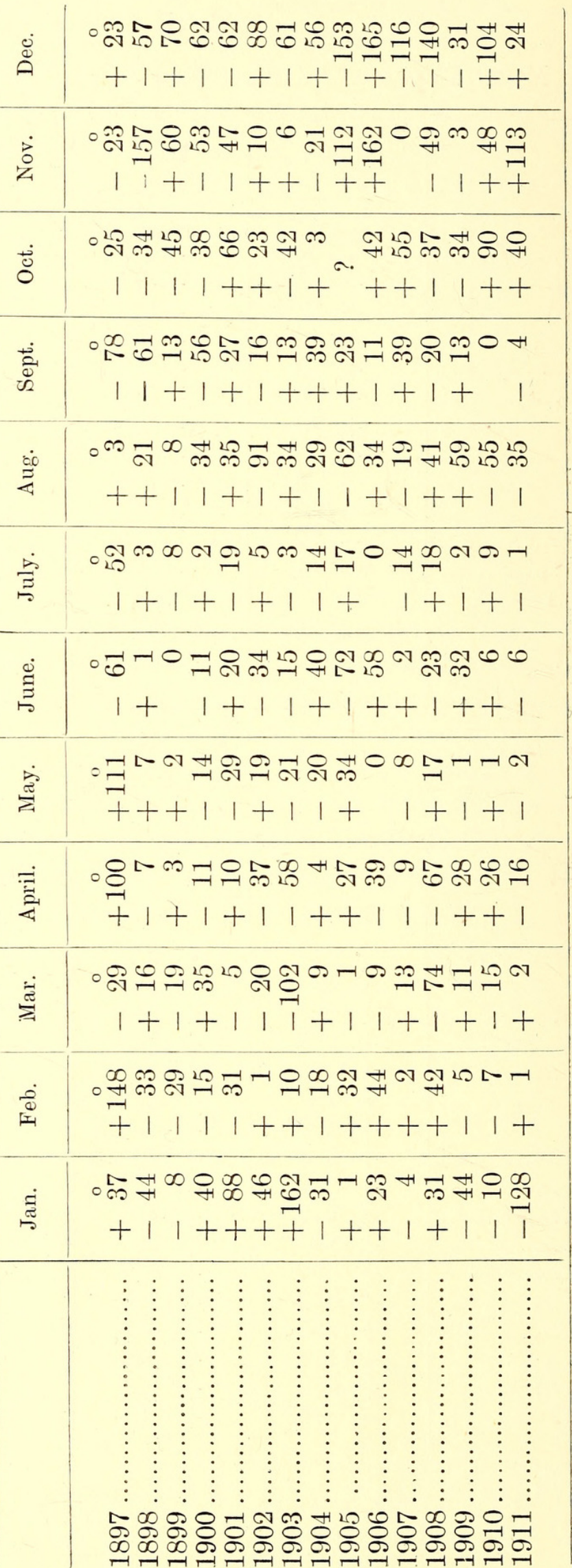




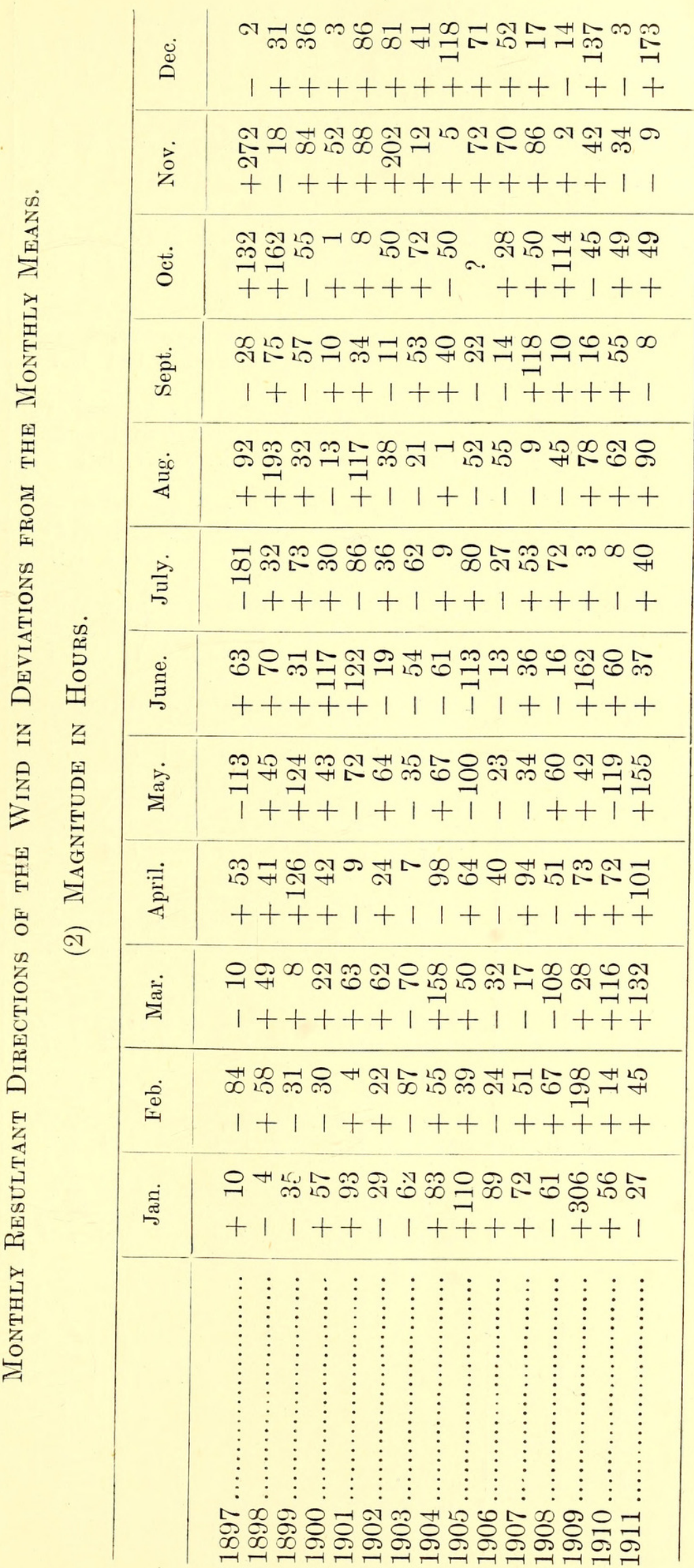




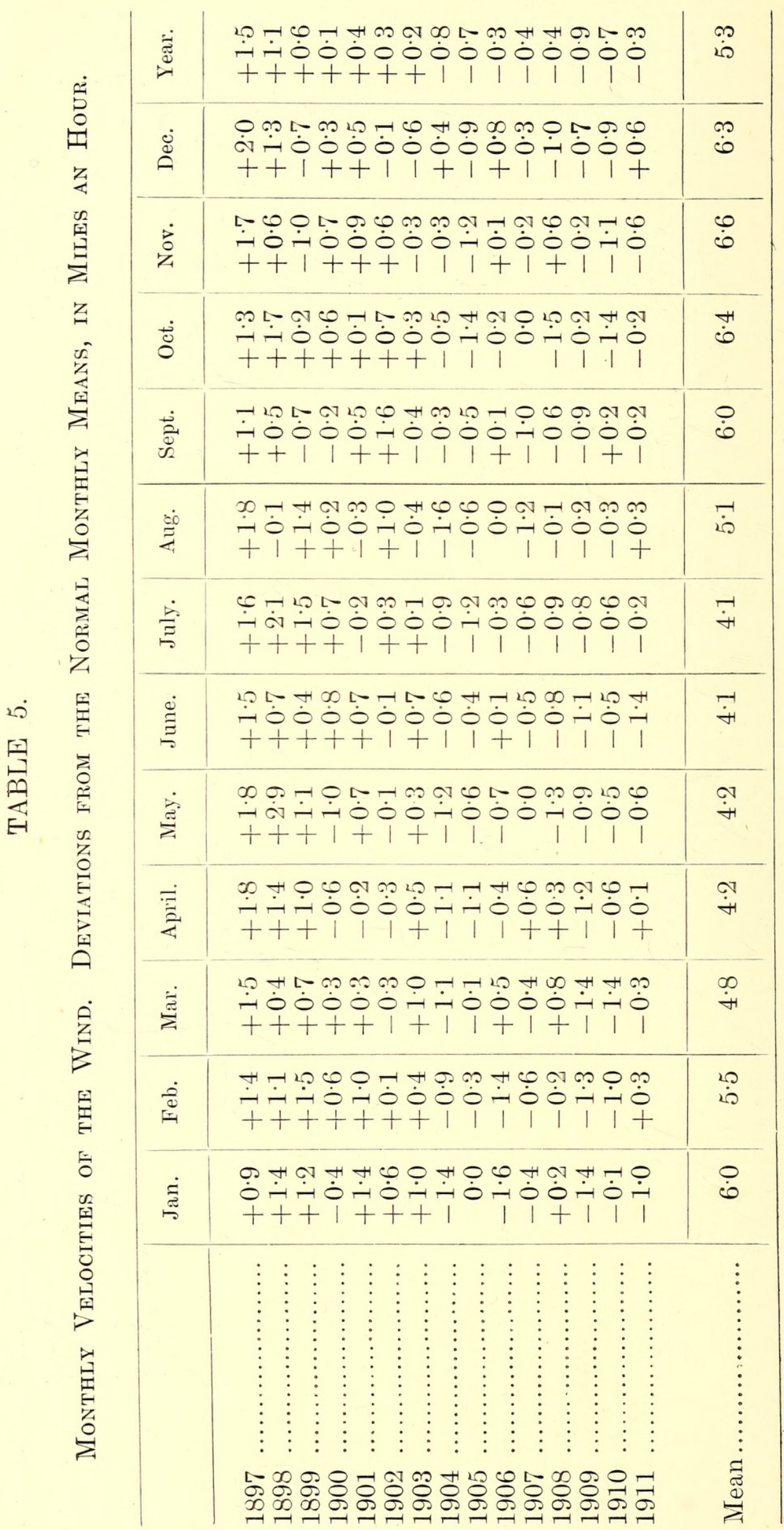




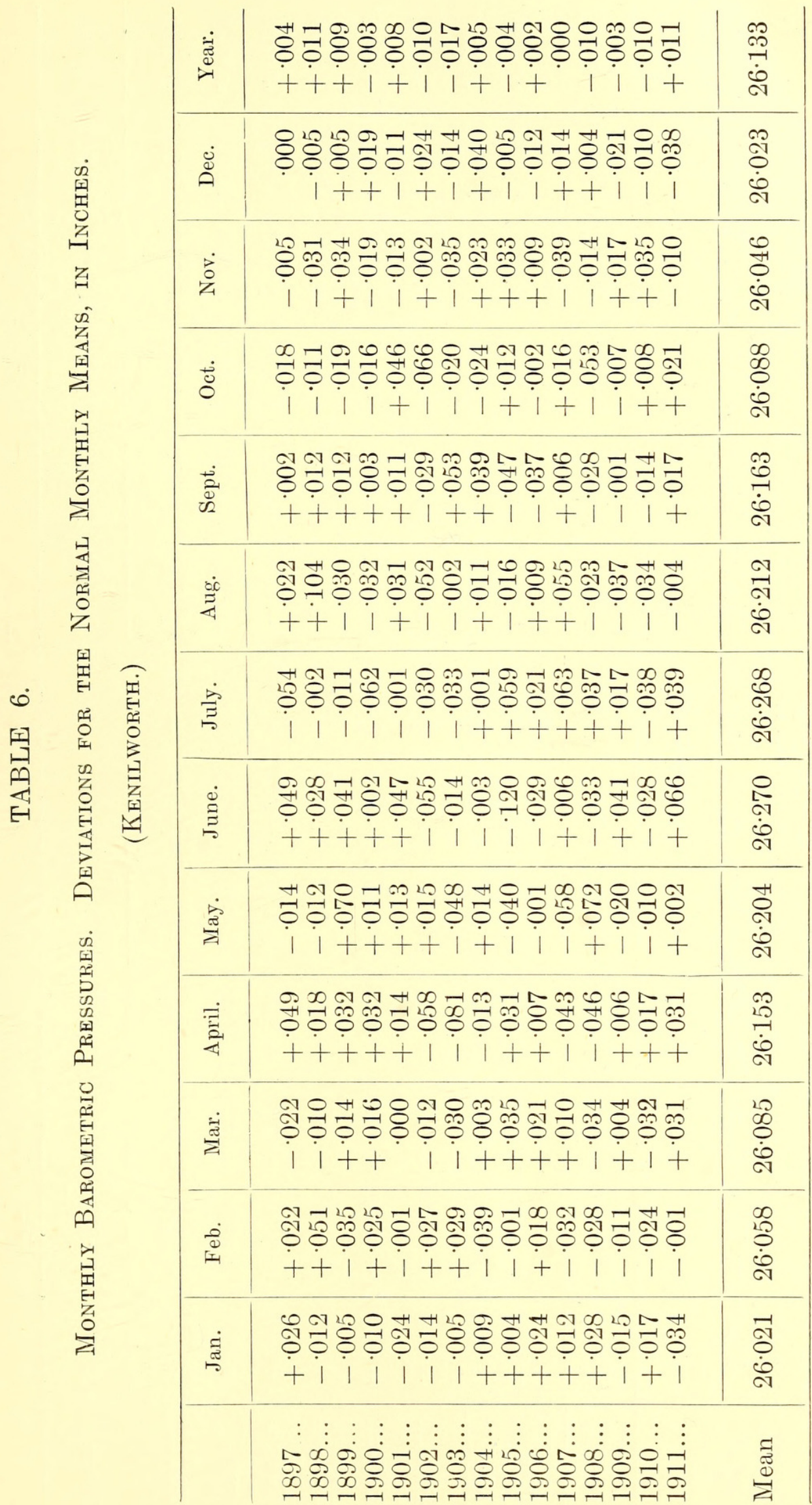




\begin{tabular}{|c|c|c|c|c|c|c|c|c|c|c|c|}
\hline \multirow{5}{*}{ 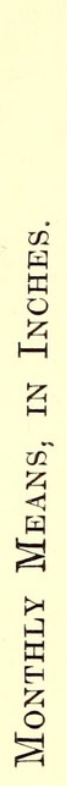 } & \multirow{14}{*}{ 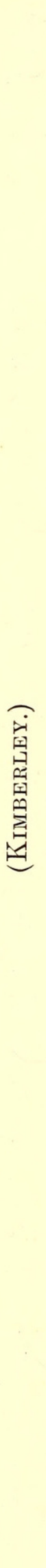 } & 峁 & 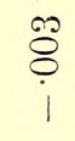 & $\begin{array}{l}\stackrel{5}{8} \\
\dot{+} \\
+\end{array}$ & $\stackrel{\vec{\delta}}{i}$ & $\begin{array}{l}0 \\
\stackrel{0}{0} \\
i\end{array}$ & $\begin{array}{l}\stackrel{5}{8} \\
\dot{+} \\
+\end{array}$ & $\begin{array}{l}\text { - } \\
\stackrel{+}{+} \\
+\end{array}$ & $\begin{array}{l}\stackrel{0}{\sigma} \\
\stackrel{\dot{+}}{+}\end{array}$ & $\begin{array}{l}\stackrel{0}{0} \\
\dot{+} \\
+\end{array}$ & $\begin{array}{l}20 \\
20 \\
0 \\
\dot{0} \\
-1\end{array}$ \\
\hline & & 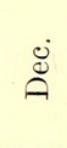 & $\begin{array}{l}\stackrel{0}{8} \\
\stackrel{8}{+} \\
+\end{array}$ & $\stackrel{8}{8}$ & $\begin{array}{l}\text { gे } \\
\dot{0} \\
i\end{array}$ & $\stackrel{\vec{s}}{\stackrel{1}{0}}$ & $\begin{array}{l}\stackrel{0}{\circ} \\
\stackrel{\leftrightarrow}{+} \\
+\end{array}$ & $\begin{array}{l}8 \\
\stackrel{8}{0} \\
\text { i }\end{array}$ & $\begin{array}{l}\stackrel{m}{+} \\
\dot{+} \\
+\end{array}$ & @) & 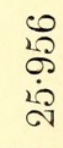 \\
\hline & & bे & $\begin{array}{l}\stackrel{02}{+} \\
\dot{+}\end{array}$ & $\begin{array}{l}0 \\
\stackrel{9}{0} \\
+ \\
+\end{array}$ & $\stackrel{m}{\stackrel{m}{+}}$ & $\stackrel{O}{0}$ & $\begin{array}{l}\stackrel{8}{8} \\
\stackrel{8}{+} \\
+\end{array}$ & $\begin{array}{l}\stackrel{o}{0} \\
\stackrel{+}{+} \\
\dot{+}\end{array}$ & $\begin{array}{l}0 \\
\dot{0} \\
\dot{+}\end{array}$ & $\stackrel{\infty}{\overrightarrow{1}}$ & $\begin{array}{l}10 \\
\text { कू } \\
\text { की } \\
\text { बे }\end{array}$ \\
\hline & & $\dot{0}$ & $\begin{array}{l}\stackrel{9}{0} \\
\stackrel{+}{+} \\
+\end{array}$ & $\begin{array}{l}\stackrel{+}{g} \\
\stackrel{+}{+} \\
+\end{array}$ & \begin{tabular}{l}
$\infty$ \\
$\varnothing$ \\
\hdashline \\
\end{tabular} & $\begin{array}{l}\overrightarrow{\text { ô }} \\
\dot{0} \\
i\end{array}$ & 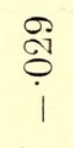 & $\begin{array}{l}\stackrel{+}{8} \\
\dot{+} \\
+\end{array}$ & $\begin{array}{l}\stackrel{9}{0} \\
\stackrel{+}{+} \\
+\end{array}$ & ণึ & 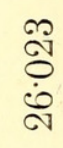 \\
\hline & & $\begin{array}{l}\dot{\vec{J}} \\
\text { Uू. }\end{array}$ & $\begin{array}{l}\stackrel{H}{+} \\
\dot{+} \\
+\end{array}$ & $\begin{array}{l}\stackrel{\infty}{8} \\
\stackrel{+}{+} \\
+\end{array}$ & $\begin{array}{l}\overrightarrow{7} \\
\dot{0} \\
i\end{array}$ & $\begin{array}{l}\rightleftarrows \\
\\
i\end{array}$ & $\begin{array}{l}\stackrel{2}{8} \\
\dot{8} \\
+\end{array}$ & $\begin{array}{l}\infty \\
\text { Oे } \\
\stackrel{1}{+} \\
+\end{array}$ & $\begin{array}{l}\stackrel{0}{1} \\
\stackrel{+}{+} \\
+\end{array}$ & $\begin{array}{l}\text { ̊े } \\
\stackrel{\leftrightarrow}{+} \\
+ \\
+\end{array}$ & $\begin{array}{l}0 \\
5 \\
0 \\
\dot{0} \\
\sigma\end{array}$ \\
\hline 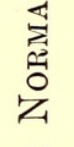 & & $\stackrel{\dot{0}}{\Xi}$ & 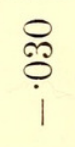 & $\begin{array}{l}\frac{9}{+} \\
\stackrel{+}{+}\end{array}$ & $\begin{array}{l}\infty \\
\stackrel{\infty}{+} \\
i\end{array}$ & $\begin{array}{l}\text { ᄋे } \\
\stackrel{\leftrightarrow}{+} \\
+\end{array}$ & $\begin{array}{l}\stackrel{3}{8} \\
\stackrel{+}{+} \\
+\end{array}$ & $\begin{array}{l}8 \\
\stackrel{8}{8}\end{array}$ & $\begin{array}{l}\stackrel{\rho}{8} \\
\stackrel{8}{+} \\
+\end{array}$ & $\begin{array}{l}\infty \\
\stackrel{2}{0} \\
\dot{+} \\
\dot{+}\end{array}$ & 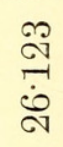 \\
\hline 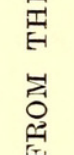 & & $\stackrel{\partial}{\Xi}$ & $\begin{array}{l}\text { L } \\
\stackrel{0}{0} \\
i\end{array}$ & $\begin{array}{l}\stackrel{+}{5} \\
\dot{C} \\
+\end{array}$ & $\begin{array}{l}\text { क् } \\
\stackrel{+}{+} \\
+\end{array}$ & $\begin{array}{l}\infty \\
\stackrel{\infty}{+} \\
+\end{array}$ & $\begin{array}{l}\stackrel{+}{8} \\
\stackrel{+}{+} \\
+\end{array}$ & $\begin{array}{l}\stackrel{2}{2} \\
\stackrel{2}{2} \\
\dot{1}\end{array}$ & $\begin{array}{l}\stackrel{\Omega}{\vec{H}} \\
\dot{+}\end{array}$ & 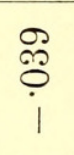 & $\begin{array}{l}\Omega \\
\stackrel{D}{0} \\
\stackrel{0}{\sigma}\end{array}$ \\
\hline 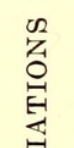 & & $\underset{\Xi}{\stackrel{\Xi}{\Xi}}$ & $\begin{array}{l}\text { ồ } \\
\stackrel{0}{+} \\
+\end{array}$ & $\underset{⿱}{ \pm}$ & $\stackrel{0}{\stackrel{0}{i}}$ & $\stackrel{\infty}{i}$ & $\stackrel{0}{\stackrel{0}{0}}$ & $\begin{array}{l}5 \\
\stackrel{5}{0} \\
\dot{+}\end{array}$ & $\begin{array}{l}20 \\
0 \\
i\end{array}$ & $\begin{array}{l}\hat{0} \\
\dot{0} \\
\dot{+}\end{array}$ & $\begin{array}{l}\frac{20}{5} \\
\dot{0} \\
\dot{\sigma}\end{array}$ \\
\hline$\dot{A}$ & & 产 & $\begin{array}{l}\stackrel{8}{8} \\
\stackrel{0}{+} \\
+\end{array}$ & 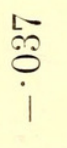 & $\begin{array}{l}20 \\
\text { ô } \\
\stackrel{1}{1} \\
i\end{array}$ & $\begin{array}{l}\frac{1}{0} \\
+ \\
+\end{array}$ & $\begin{array}{l}8 \\
8 \\
\end{array}$ & $\begin{array}{l}\frac{\Delta}{0} \\
\dot{+}\end{array}$ & $\begin{array}{l}\infty \\
\stackrel{\infty}{+} \\
\dot{+}\end{array}$ & \begin{tabular}{l}
0 \\
8 \\
\hdashline \\
$i$
\end{tabular} & 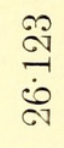 \\
\hline 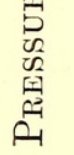 & & $\dot{\vec{Z}}$ & $\begin{array}{l}\text { o } \\
\text { ô } \\
\text { i }\end{array}$ & $\begin{array}{l}\stackrel{20}{0} \\
\dot{+}\end{array}$ & $\begin{array}{l}\overrightarrow{\text { ô }} \\
\dot{i}\end{array}$ & $\frac{0}{0}$ & $\begin{array}{l}\overrightarrow{8} \\
\dot{+} \\
+\end{array}$ & \begin{tabular}{l}
0 \\
8 \\
\hdashline \\
\end{tabular} & $\begin{array}{l}\text { 웅 } \\
\text { i }\end{array}$ & $\begin{array}{l}\dot{0} \\
\stackrel{+}{+} \\
+\end{array}$ & $\begin{array}{l}20 \\
\infty \\
0 \\
\dot{0} \\
\text { ov }\end{array}$ \\
\hline 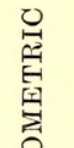 & & 离 & $\begin{array}{l}\infty \\
\stackrel{0}{0} \\
+\end{array}$ & $\begin{array}{l}\stackrel{\infty}{0} \\
\dot{+}\end{array}$ & 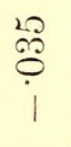 & $\begin{array}{l}\stackrel{9}{+} \\
\dot{+} \\
+\end{array}$ & $\begin{array}{l}20 \\
i \\
i\end{array}$ & $\begin{array}{l}29 \\
\stackrel{8}{8} \\
+\end{array}$ & $\begin{array}{l}0 \\
8 \\
\dot{+} \\
+\end{array}$ & $\begin{array}{l}+ \\
\stackrel{n}{9} \\
\dot{m}\end{array}$ & 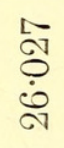 \\
\hline 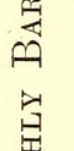 & & $\dot{\overrightarrow{0}}$ & $\begin{array}{l}0 \\
0 \\
i \\
i\end{array}$ & $\stackrel{\square}{\circ}$ & $\begin{array}{l}\text { @ै } \\
\stackrel{\leftrightarrow}{1}\end{array}$ & $\stackrel{\frac{N}{0}}{i}$ & $\begin{array}{l}\text { 管 } \\
+ \\
+\end{array}$ & $\frac{20}{\grave{0}}$ & $\begin{array}{l}\stackrel{8}{\circ} \\
\stackrel{9}{+} \\
\dot{+}\end{array}$ & $\begin{array}{l}\stackrel{0}{+} \\
\dot{1} \\
+\end{array}$ & 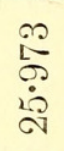 \\
\hline$\stackrel{5}{\stackrel{5}{6}}$ & & $\stackrel{\Xi}{\stackrel{\Xi}{\Xi}}$ & $\begin{array}{l}20 \\
\stackrel{20}{9} \\
i\end{array}$ & $\begin{array}{l}\stackrel{8}{8} \\
\dot{+}\end{array}$ & $\begin{array}{l}\text { Oै } \\
\stackrel{0}{0} \\
\text { i }\end{array}$ & 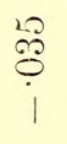 & $\begin{array}{l}\infty \\
\text { ه़ } \\
\stackrel{1}{1} \\
+\end{array}$ & $\begin{array}{l}\mathscr{8} \\
\stackrel{8}{8} \\
+\end{array}$ & $\begin{array}{l}\vec{g} \\
\stackrel{\leftrightarrow}{+} \\
+\end{array}$ & $\begin{array}{l}\text { क्ष } \\
\stackrel{+}{+} \\
+\end{array}$ & $\begin{array}{l}\text { ने } \\
\text { id } \\
\text { id }\end{array}$ \\
\hline & & & $\begin{array}{c}\vdots \\
\stackrel{\infty}{\infty} \\
\stackrel{\infty}{-1}\end{array}$ & $\begin{array}{c}\vdots \\
-1 \\
-\infty \\
-1 \\
-1\end{array}$ & $\begin{array}{c}\vdots \\
\stackrel{N}{\mathscr{D}} \\
\stackrel{\infty}{-1}\end{array}$ & $\begin{array}{c}\vdots \\
\stackrel{\infty}{\mathscr{D}} \\
\stackrel{\infty}{-1}\end{array}$ & $\begin{array}{c}\vdots \\
\text { मे } \\
\stackrel{D}{-1}\end{array}$ & $\begin{array}{l}\vdots \\
20 \\
\infty \\
\infty \\
\infty \\
-1\end{array}$ & $\begin{array}{c}\vdots \\
\infty \\
\infty \\
\infty \\
-1\end{array}$ & $\begin{array}{c}\vdots \\
\stackrel{\infty}{\infty} \\
\infty \\
\infty\end{array}$ & 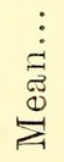 \\
\hline
\end{tabular}


A Preliminary Survey of the Meteorology of Kimberley.

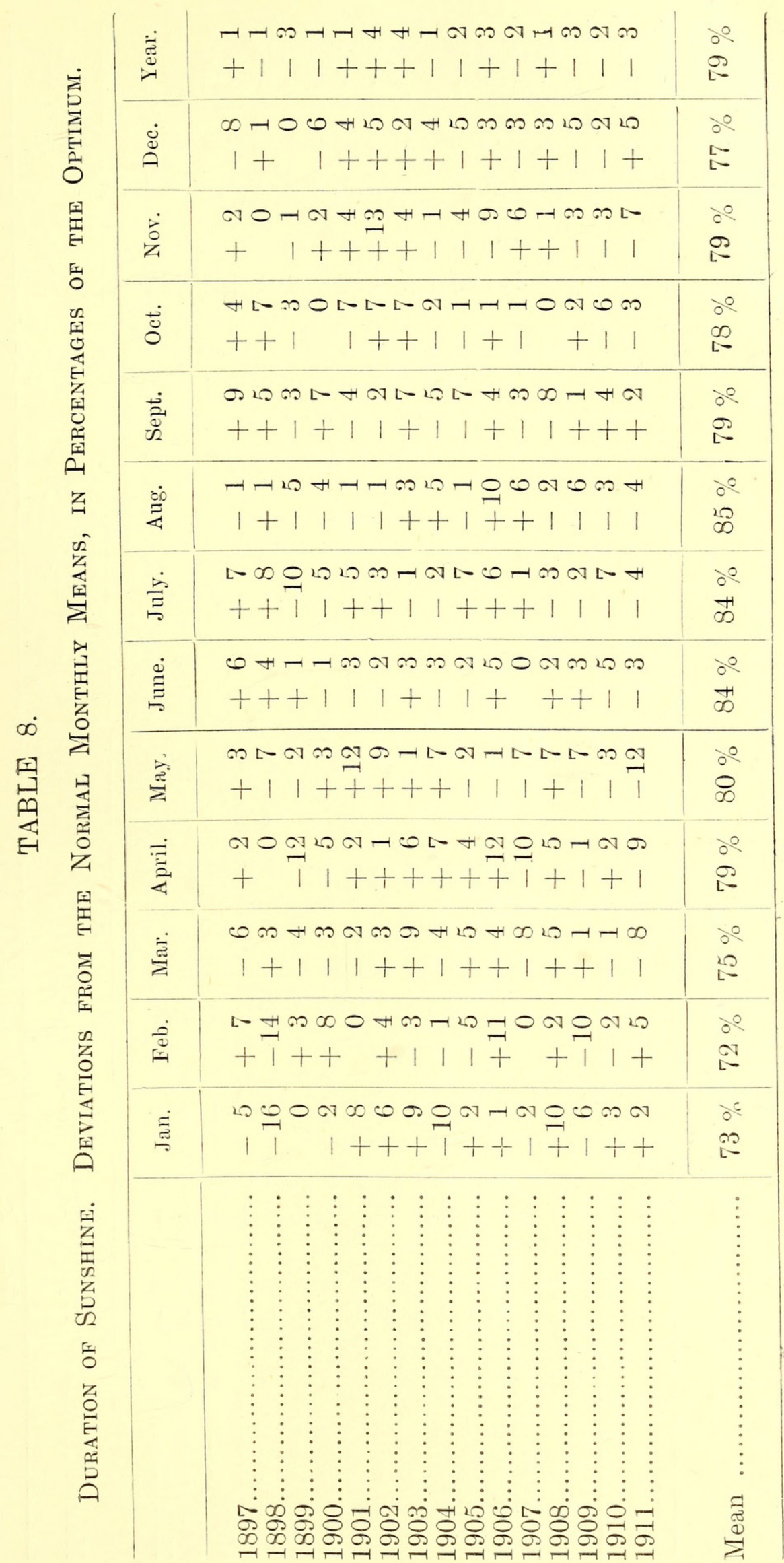


Transactions of the Royal Society of South Africa.

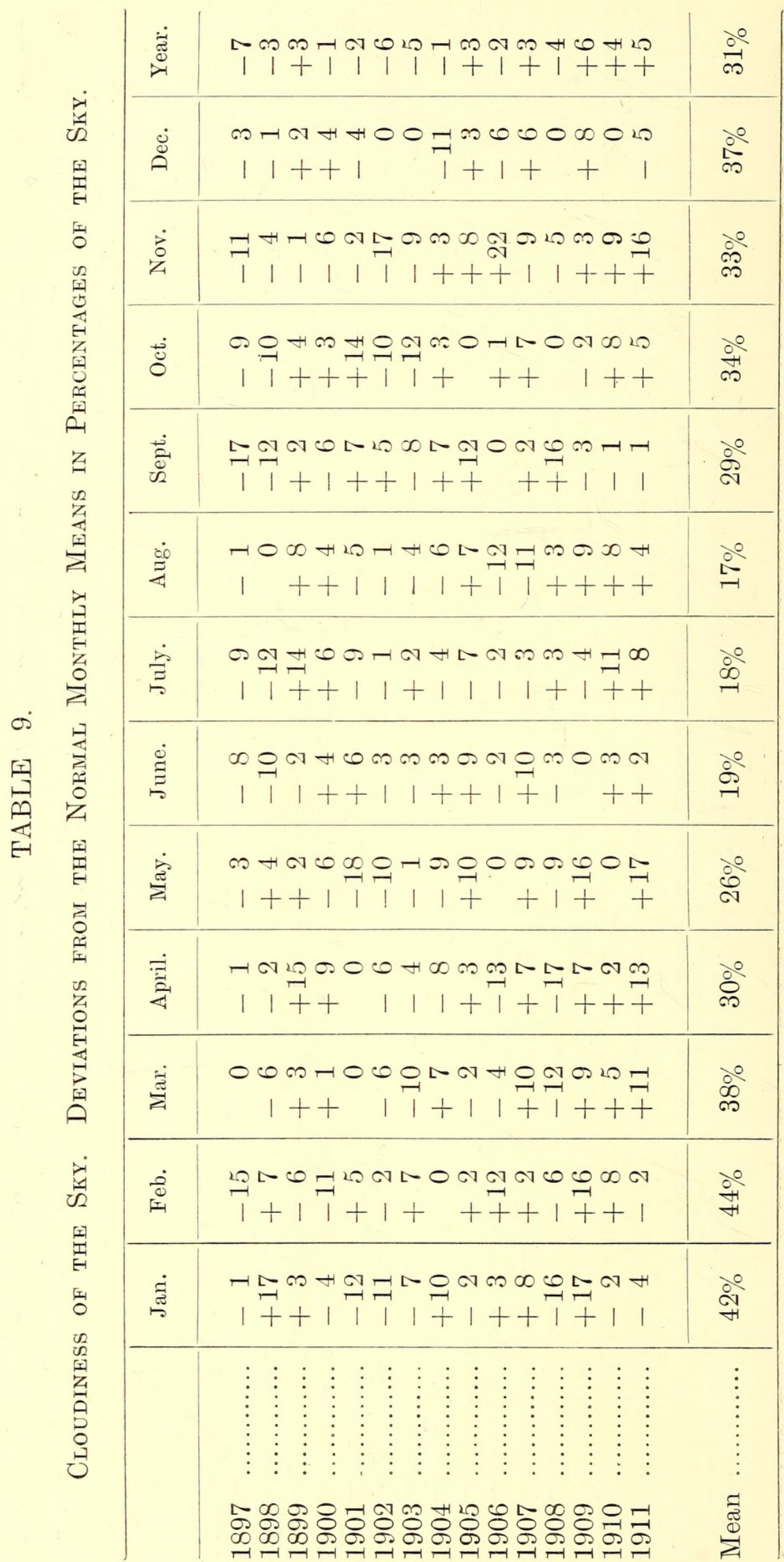


A Preliminary Survey of the Meteorology of Kimberley.

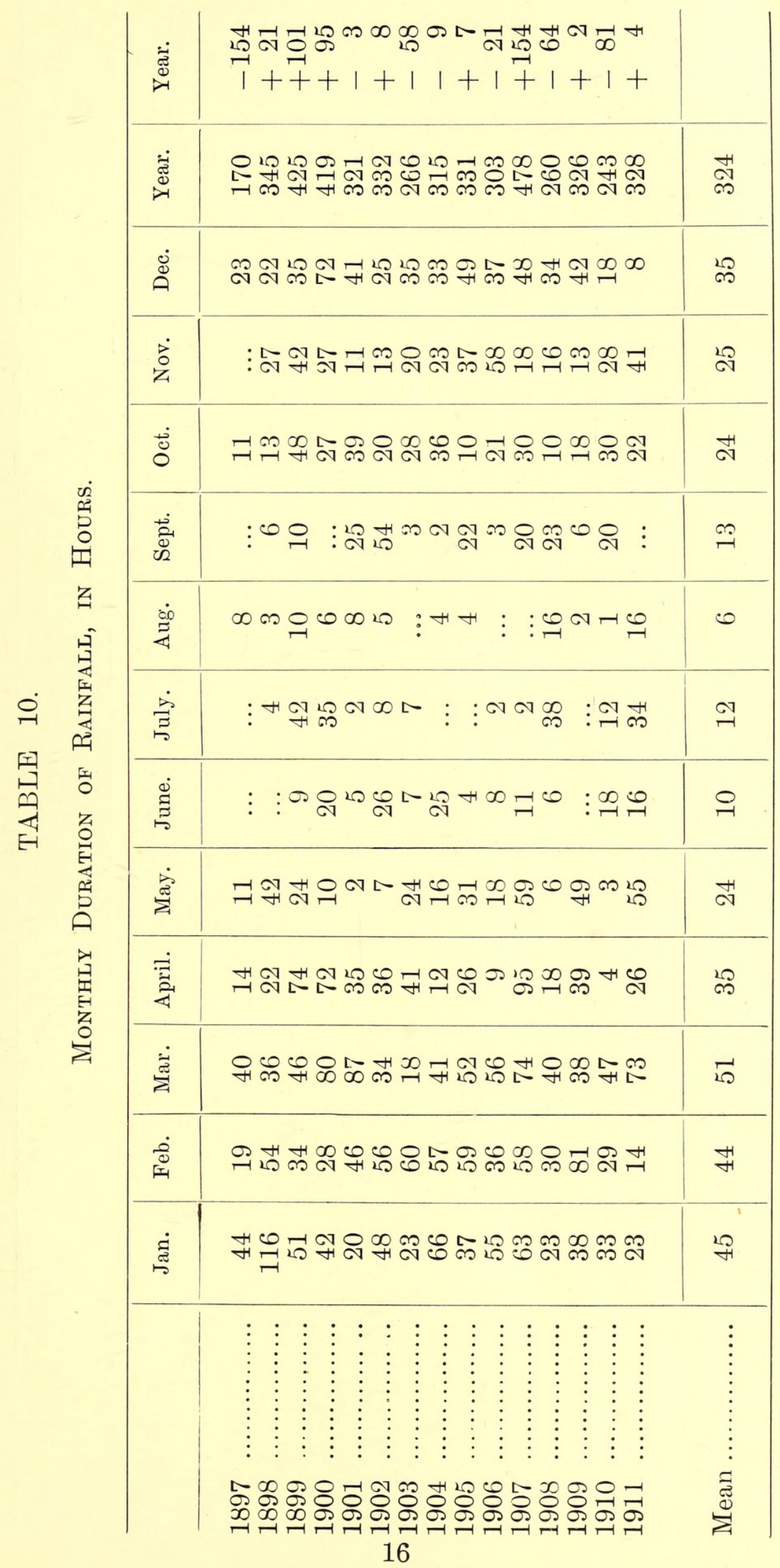




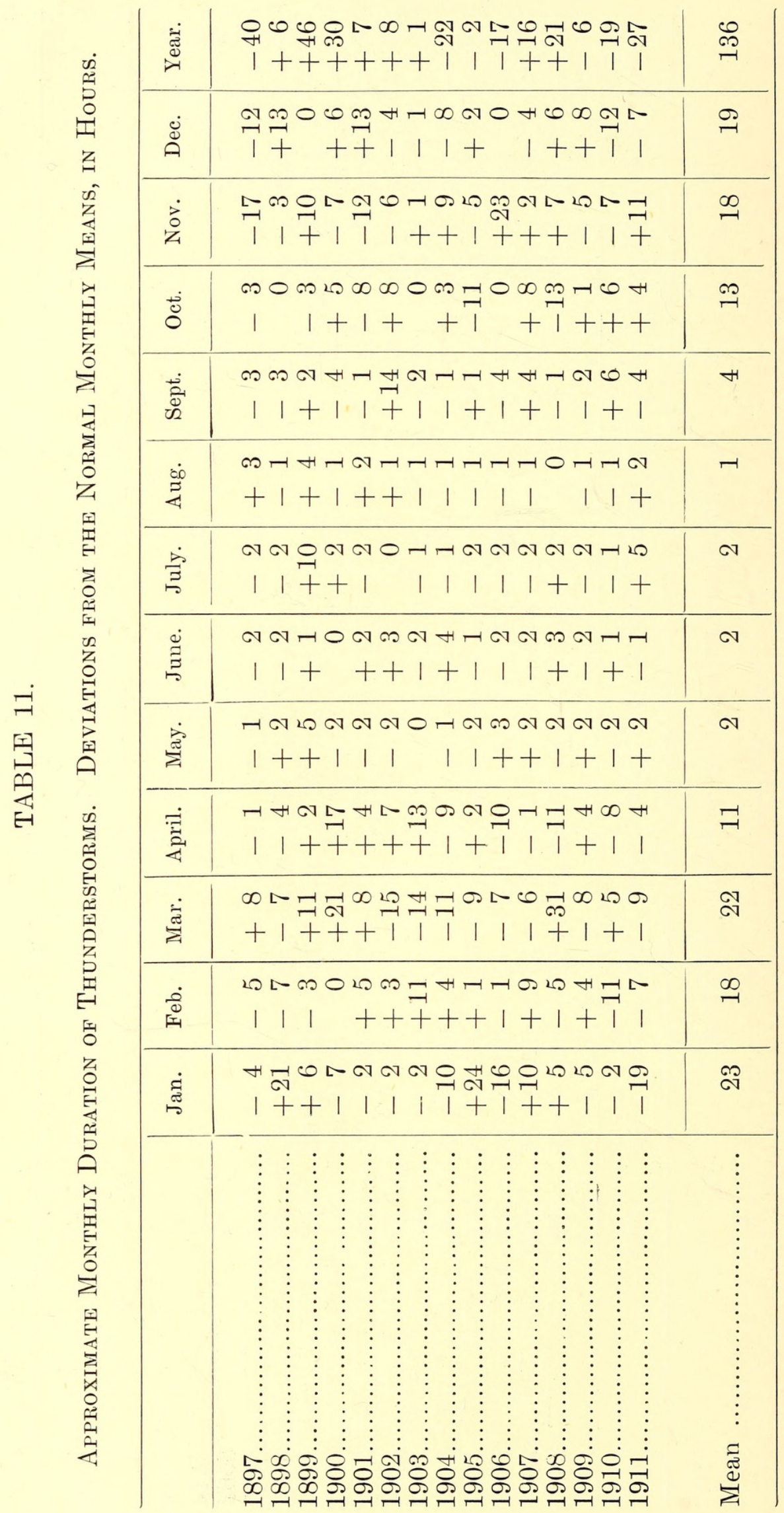


A Preliminary Survey of the Meteorology of Kimberley.

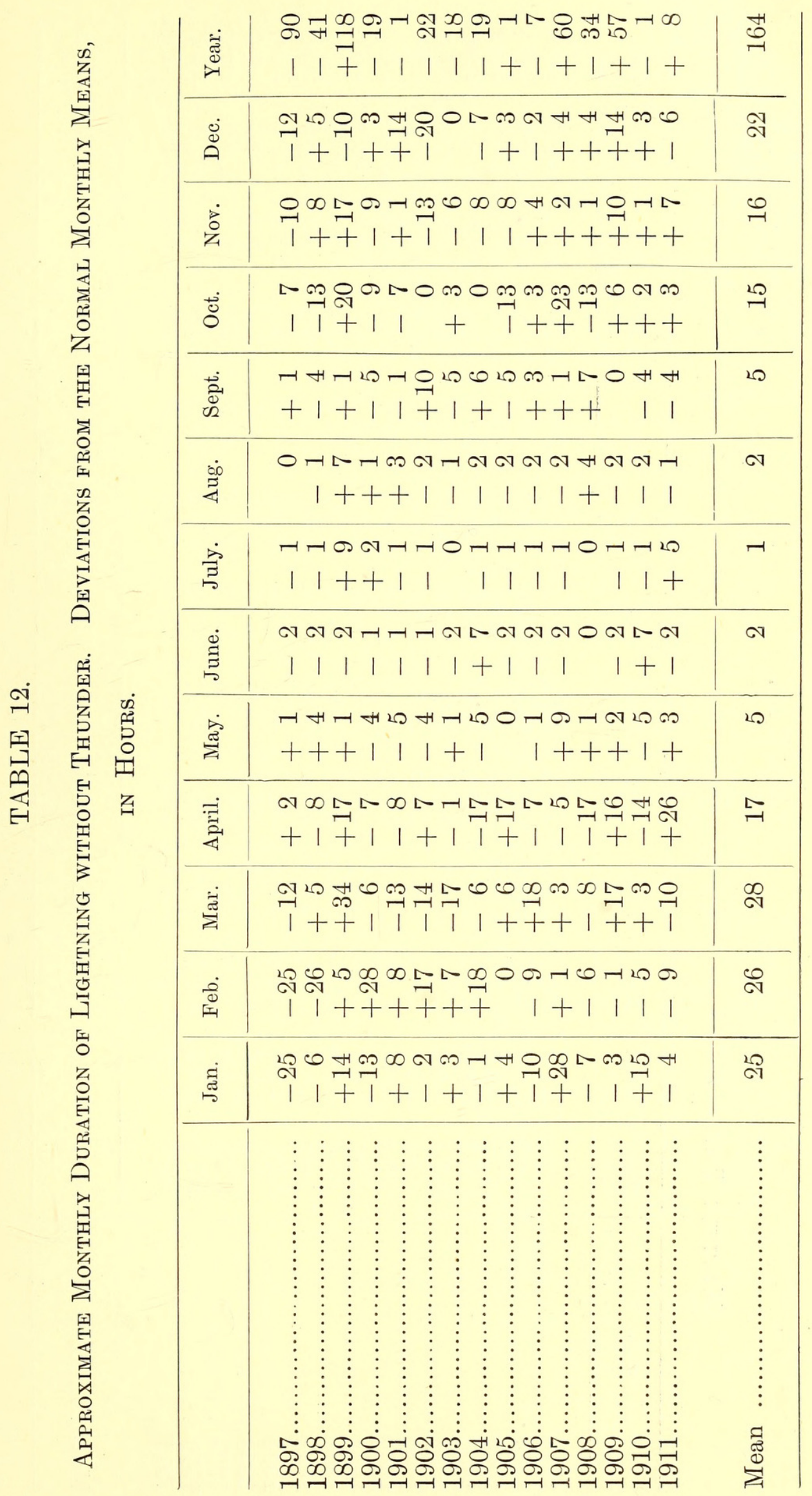




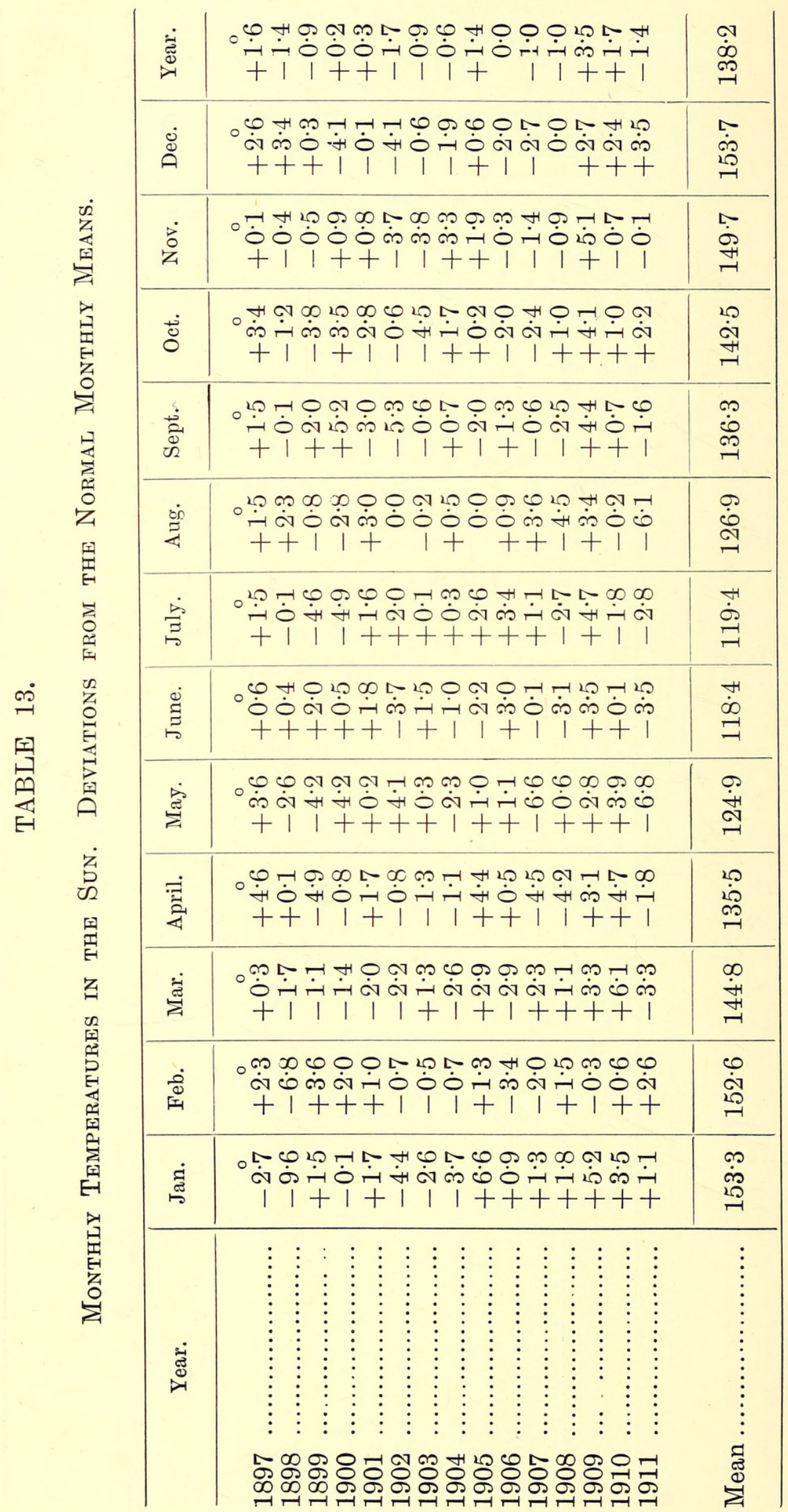




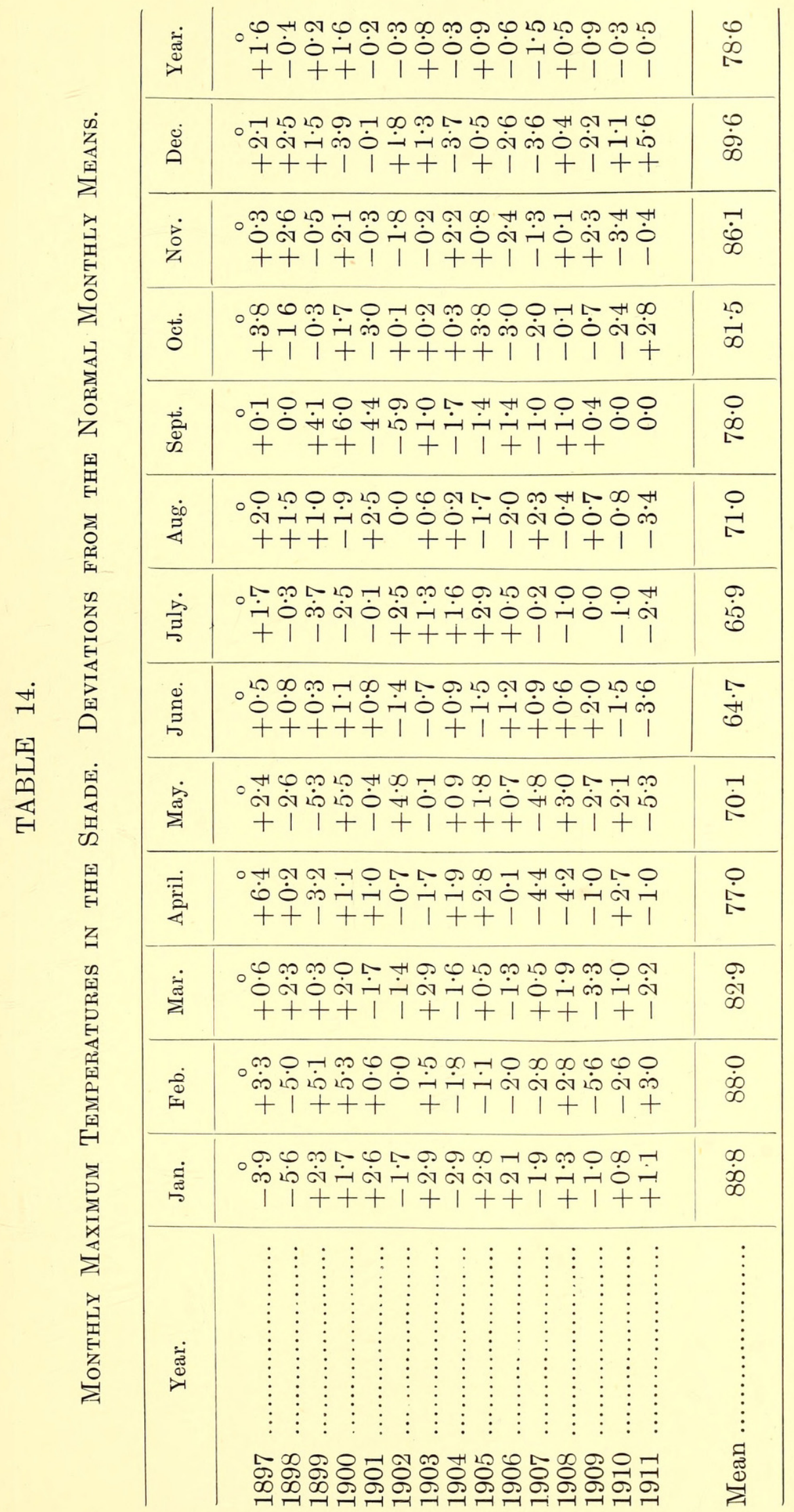




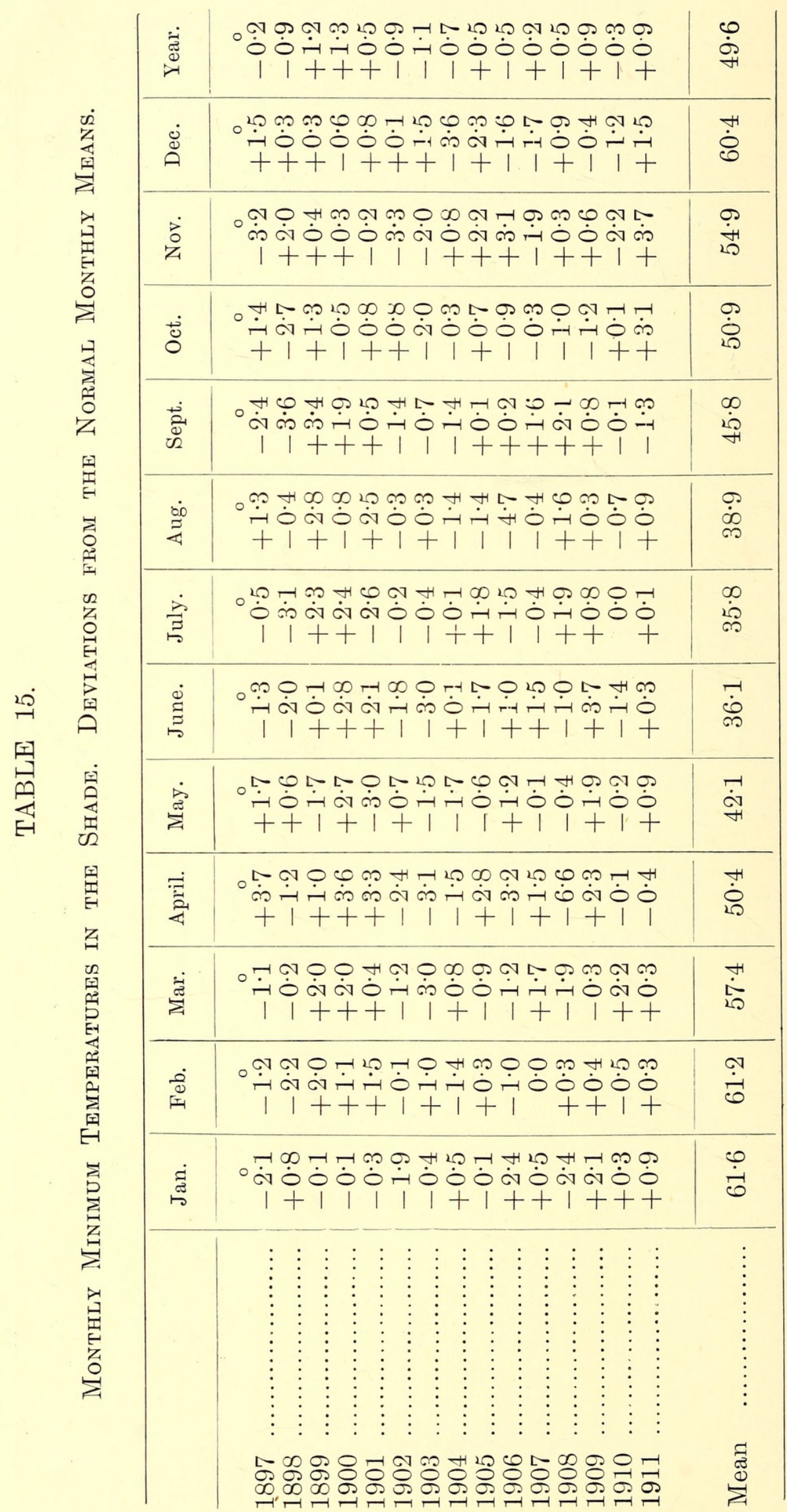




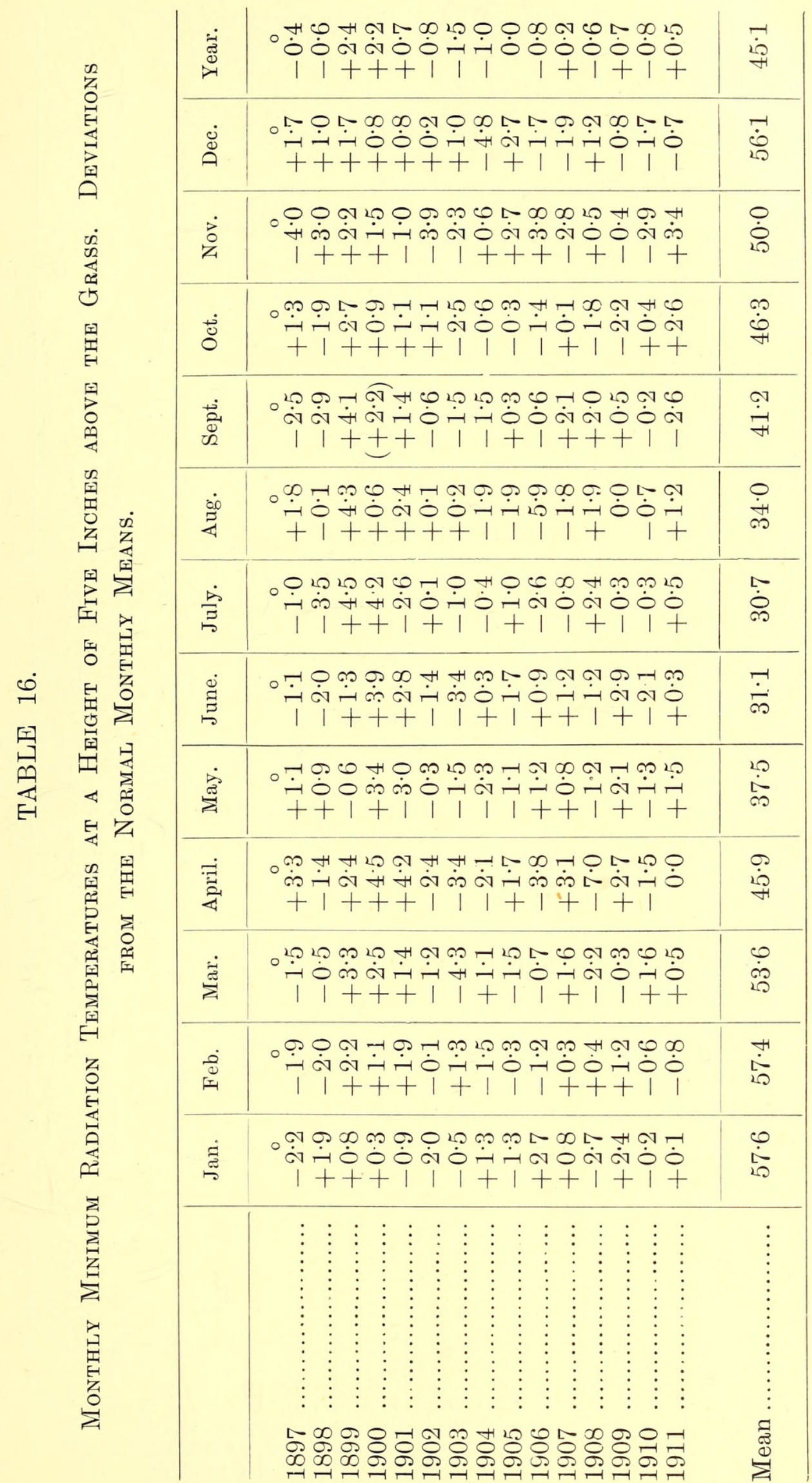




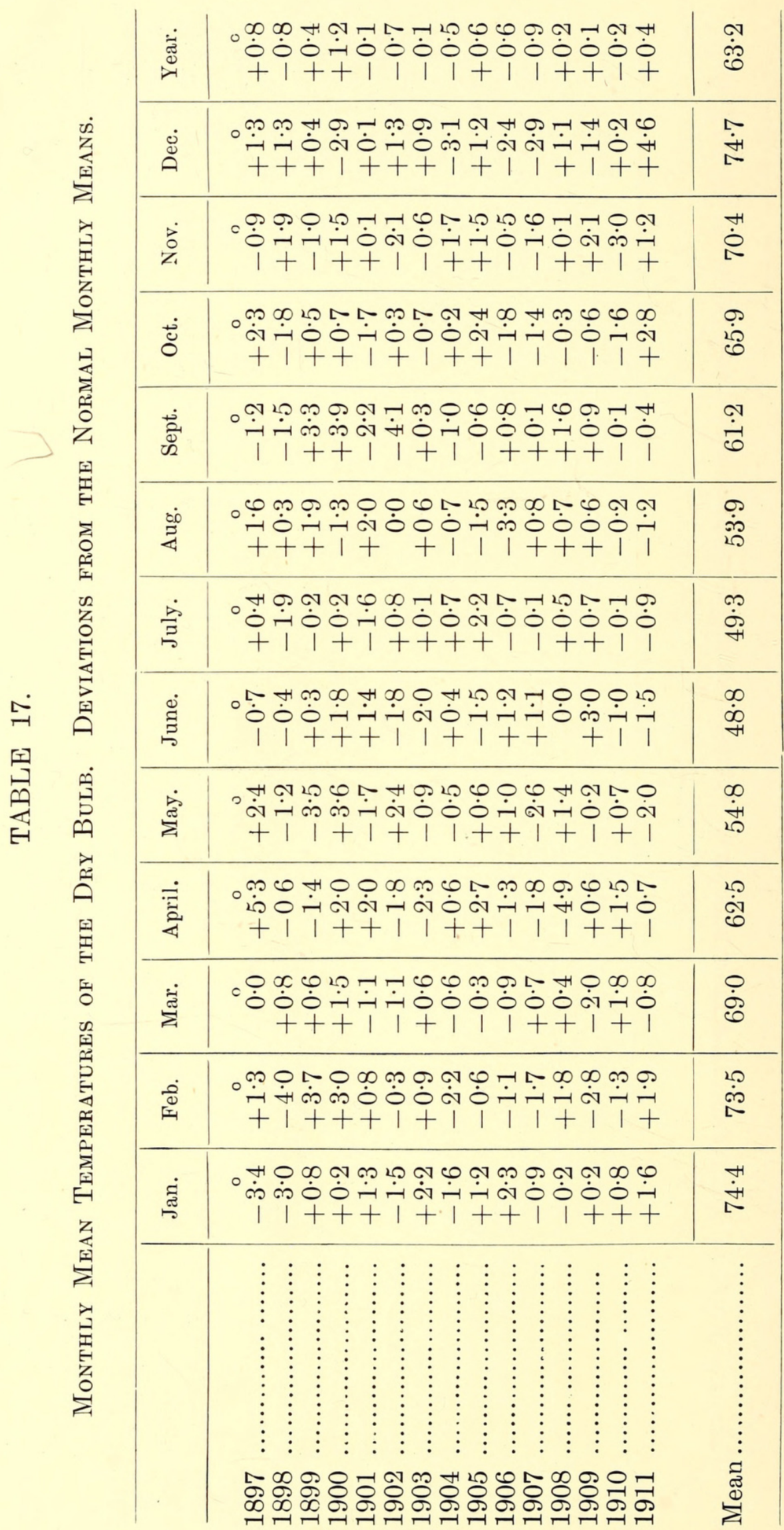




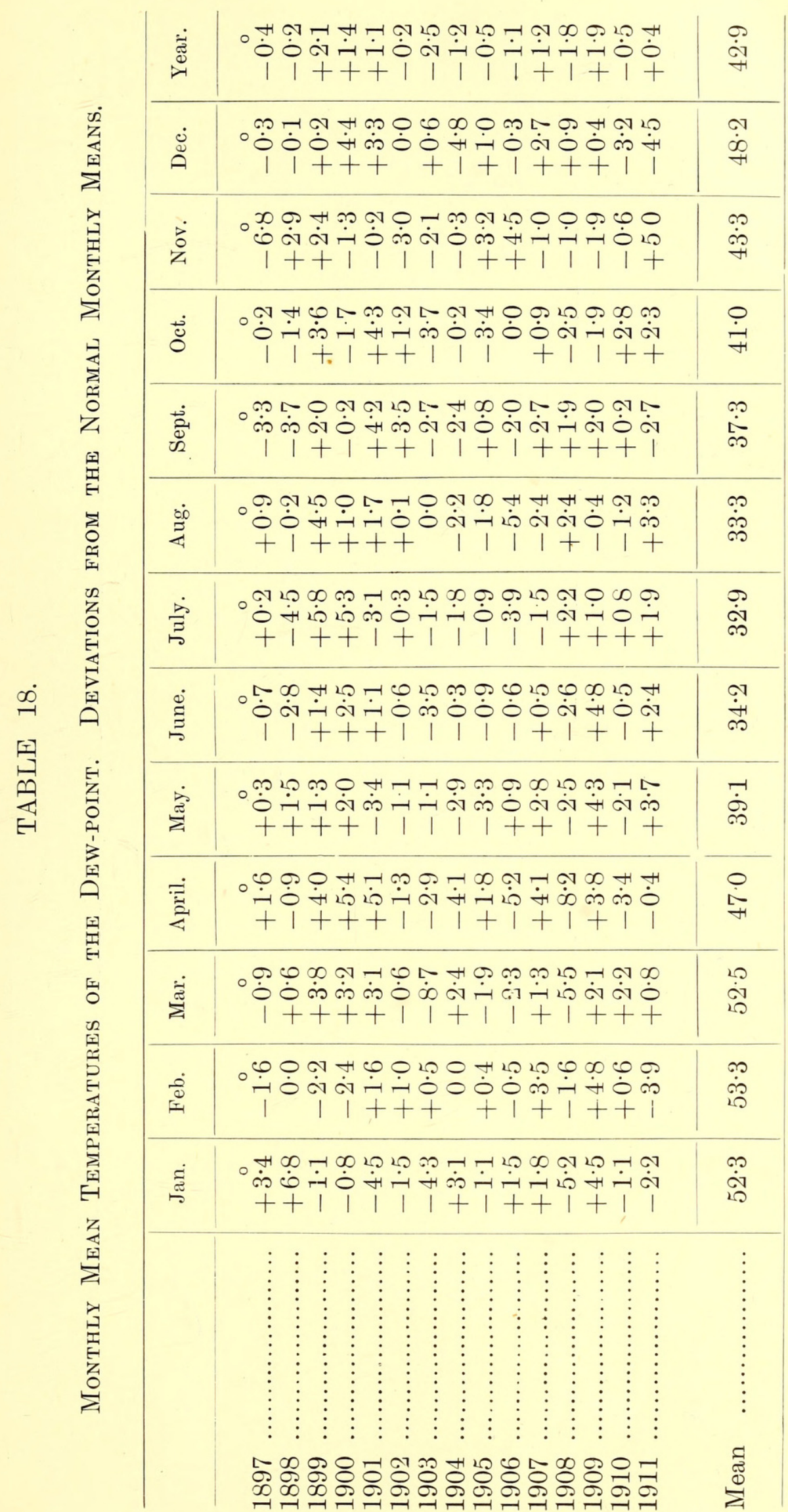




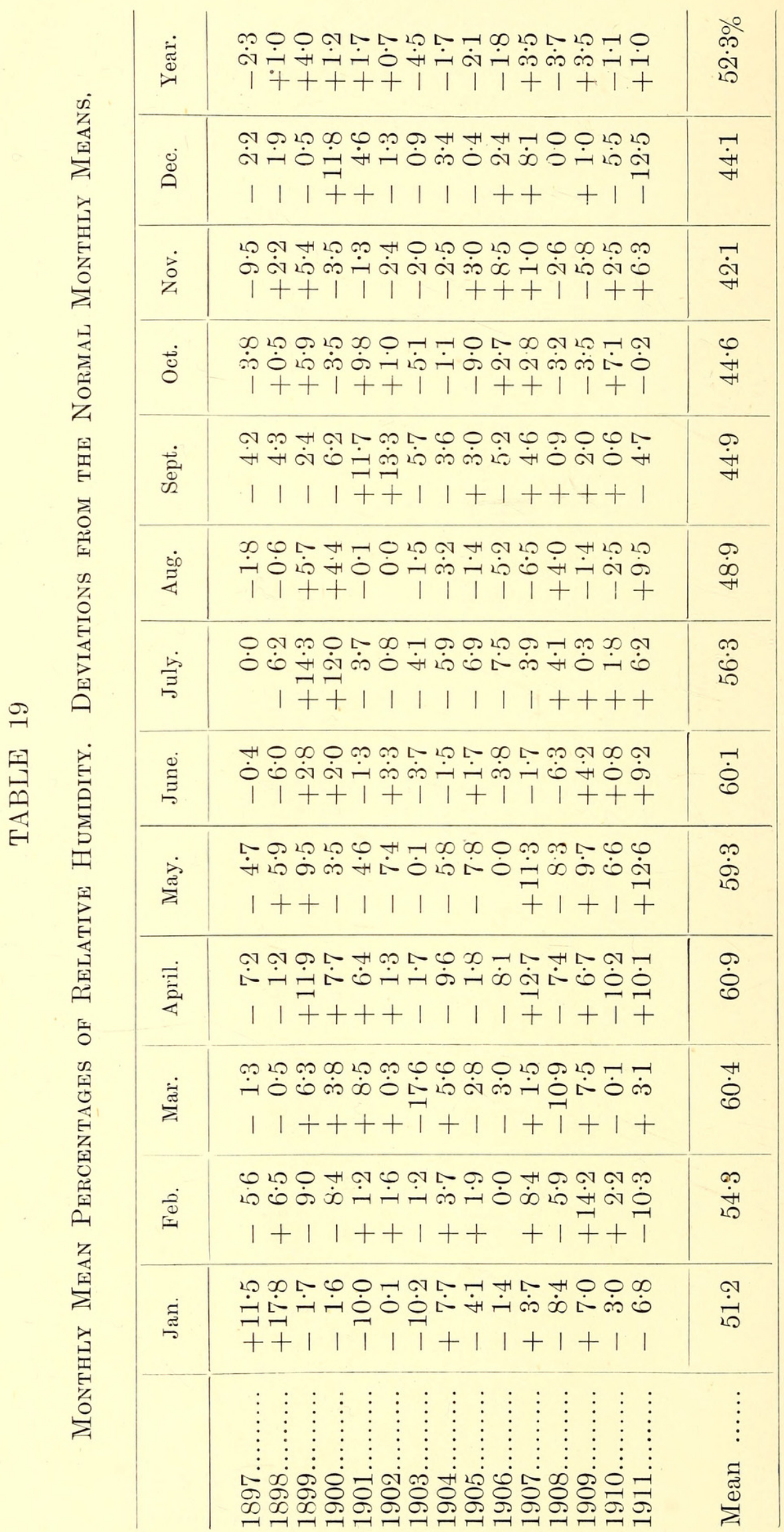


TABLE 20.

Annual Rainfall.

\begin{tabular}{|c|c|c|c|}
\hline Year. & Kimberley. & Year. & Kenilworth. \\
\hline 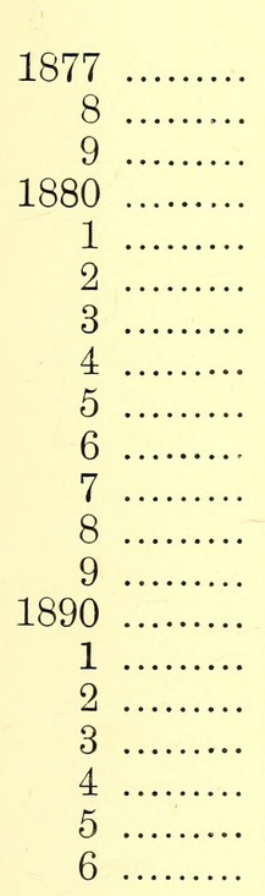 & $\begin{array}{r}\text { Inches. } \\
13 \cdot 58 \\
9 \cdot 34 \\
19 \cdot 38 \\
15 \cdot 43 \\
30 \cdot 30 \\
14 \cdot 77 \\
11 \cdot 21 \\
18 \cdot 43 \\
9 \cdot 63 \\
14 \cdot 44 \\
18 \cdot 74 \\
17 \cdot 34 \\
17 \cdot 49 \\
23 \cdot 11 \\
31 \cdot 30 \\
12 \cdot 88 \\
16 \cdot 25 \\
25 \cdot 03 \\
15 \cdot 98 \\
19 \cdot 86\end{array}$ & $\begin{aligned} & 1894 \ldots \ldots \\
& 5 \ldots \ldots \\
& 6 \ldots \ldots \\
& 7 \ldots \ldots \\
& 8 \ldots \ldots \\
& 9 \ldots \ldots \\
& 1900 \ldots \ldots \\
& 1 \ldots \ldots \\
& 2 \ldots \ldots \\
& 3 \ldots \ldots \\
& 4 \ldots \ldots \\
& 5 \ldots \ldots \\
& 6 \ldots \ldots \\
& 7 \ldots \ldots \\
& 8 \ldots \ldots \\
& 9 \ldots \ldots \\
& 1910 \ldots \ldots \\
& 1 \ldots \ldots \\
&\end{aligned}$ & $\begin{array}{r}\text { Inches. } \\
24 \cdot 51 \\
15 \cdot 60 \\
21 \cdot 07 \\
8 \cdot 85 \\
18 \cdot 29 \\
19 \cdot 39 \\
18 \cdot 78 \\
22 \cdot 2 \cdot 3 \\
22 \cdot 25 \\
12 \cdot 25 \\
17 \cdot 64 \\
14 \cdot 02 \\
17 \cdot 89 \\
24 \cdot 74 \\
12 \cdot 92 \\
20 \cdot 39 \\
15 \cdot 44 \\
13 \cdot 10\end{array}$ \\
\hline
\end{tabular}




\section{$2 \mathrm{BHL}$ Biodiversity Heritage Library}

Sutton, J R . 1913. "A PRELIMINARY SURVEY OF THE METEOROLOGY OF

KIMBERLEY." Transactions of the Royal Society of South Africa 3, 205-229. https://doi.org/10.1080/00359191309519693.

View This Item Online: https://www.biodiversitylibrary.org/item/182860

DOI: https://doi.org/10.1080/00359191309519693

Permalink: https://www.biodiversitylibrary.org/partpdf/175515

\section{Holding Institution}

Smithsonian Libraries

\section{Sponsored by}

Biodiversity Heritage Library

\section{Copyright \& Reuse}

Copyright Status: Not in copyright. The BHL knows of no copyright restrictions on this item.

This document was created from content at the Biodiversity Heritage Library, the world's largest open access digital library for biodiversity literature and archives. Visit BHL at https://www.biodiversitylibrary.org. 